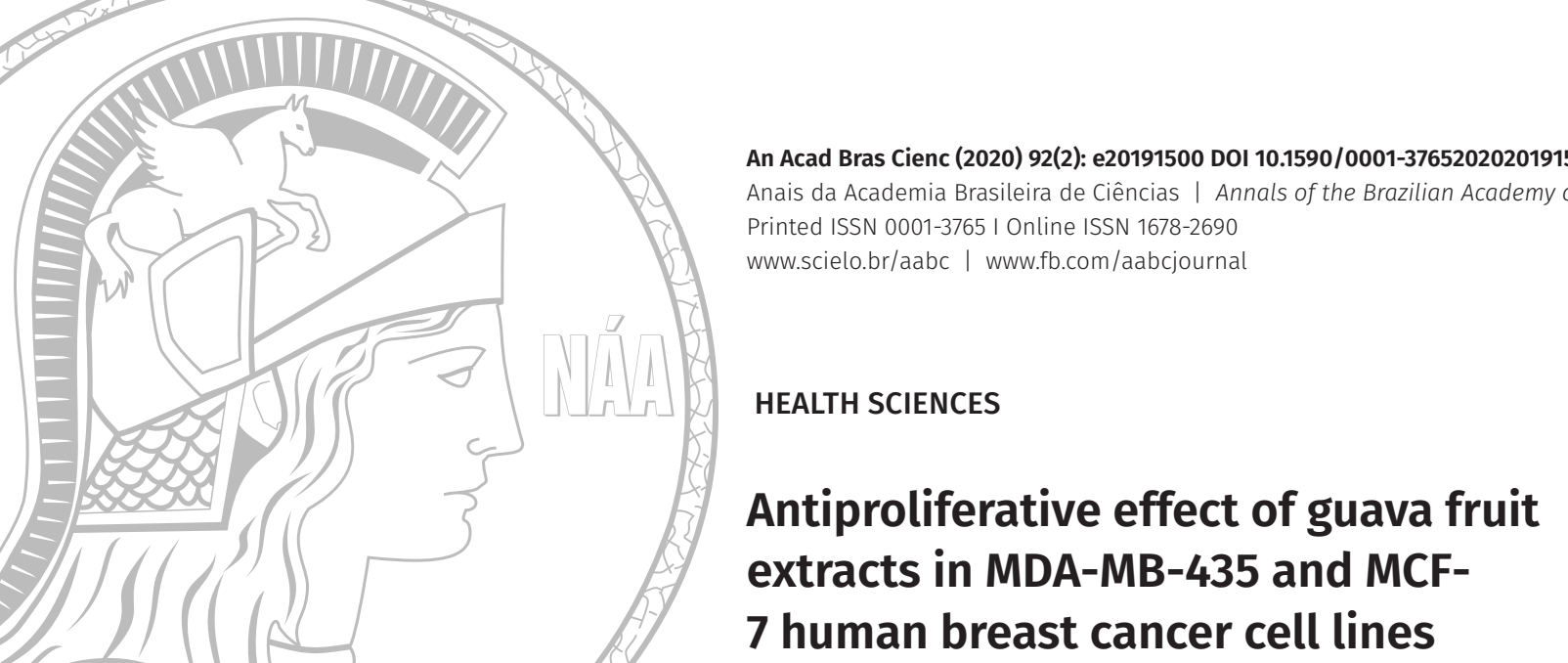

\title{
Antiproliferative effect of guava fruit extracts in MDA-MB-435 and MCF- 7 human breast cancer cell lines
}

\author{
MARIANA G. CORREA, JESSICA S. COUTO, BRUNO B. TRINDADE, JOEL P. ABREU, \\ VANIA M. NAKAJIMA, FELIPE L. OLIVEIRA, ADRIANA FARAH \& \\ ANDERSON J. TEODORO
}

\begin{abstract}
Breast cancer is the most frequent and lethal neoplastic disease among women worldwide. Psidium Guajava is a promising functional food against cancer, owing to a variety of bioactive compounds. This study aimed to evaluate the anticarcinogenic potential of Pedro Sato (PS), Hitigio (HI) and Tsumori (TS) guava cultivars fruit pulp extracts in MDA-MB-435 and MCF-7 human breast cancer cells. The antioxidant capacity of the extracts and their effect on cell viability, cell cycle and apoptosis were assessed. Additionally, the concentration of carotenoids, total phenolics, ascorbic acid and other physicochemical parameters were evaluated. PS pulp extract showed the highest in vitro antioxidative activity by all tested methods, as well as the highest content of lycopene and total phenolics, while TS pulp extract presented the highest concentration of $\beta$-carotene. After 48 hours treatment, all guava cultivars' extracts caused reduction of MDA-MB-435 and MCF-7 cells viability, with PS and HI being the most effective extracts. All guava extracts caused MDA-MB-435 and MCF-7 cell count reduction in G0/G1 and G2/M phases and increased apoptosis. The present results strongly suggest that guava pulp exerts antiproliferative effect on breast adenocarcinoma cells.
\end{abstract}

Key words: breast adenocarcinoma, cancer, carotenoids, guava fruit, MDA-MB-435 cell line, MCF-7 cell line.

\section{INTRODUCTION}

Cancer is a complex disease characterized by an increase in cell proliferation or a reduction in cell death or both (Lee \& Park 2010, Toyokuni 2016). It is caused by endogenous and exogenous factors related to the overproduction of free reactive radicals or reactive oxygen species (ROS). Oxidative stress induced by free radicals can lead to base mutation, single- and doublestrand breaks, DNA cross-linking, chromosomal breakage and rearrangement, disruption of function through lipid peroxidation of cell membranes, and degradation of nucleic acids, causing progressive mutations (Liu 2004, Chahal et al. 2018, Gonzalez et al. 2018).

According to reports from the International Agency for Research on Cancer (IARC), the incidence of cancer is increasing worldwide. Ten million cancer cases and 6 million deaths occurred in 2000, while in 201818.1 million new cases have been estimated, with 9.6 million deaths worldwide (IARC/WHO 2018). Together with lung cancer, breast cancer is the most frequently diagnosed type of cancer around the world, the $5^{\text {th }}$ type of cancer to cause deaths in general and the $1^{\text {st }}$ to cause deaths in women in 2018 (Bray et al. 2018, INCA 2019). 
Once breast cancer is installed, most complications, including death, are due to metastasis. Mortality has been reduced with surgery, radiotherapy, chemotherapy and other therapies. However, such treatments have often caused serious adverse effects. Thus, the possibility of prevention and co-treatment through natural approaches are increasingly becoming the focus of interest and research in recent years (Brisken \& O'Malley 2010, WHO 2013, Al-Mahmood et al. 2018).

Potentially, cancer-inducing oxidative damage might be prevented or limited by enzymatic and non-enzymatic antioxidants which are located in the intracellular and extracellular environments to detoxify free radicals, acting as biological response modifiers supporting immune system function and protecting living cells against damage from ROS (Liu 2004, Chahal et al. 2018). Dietary antioxidants include components of some fruits and vegetables, which act as radical scavengers, hydrogen donors, electron donors, peroxide decomposers, singlet oxygen quenchers, enzyme inhibitors, synergists, and metal-chelating agents, modulating biochemical processes related to cell proliferation, differentiation, apoptosis, inflammation, angiogenesis, and metastasis (Niedzwiecki et al. 2016). Among the main dietary antioxidants are phenolic compounds, carotenoid pigments and ascorbic acid (Ramos 2008, Roomi et al. 2016, Fiedor \& Burda 2014).

From the tree of the Myrtaceae family, guava is a native fruit of tropical America that has spread to all tropical and subtropical regions of the world. In traditional South American, Asian and African medicine, guava root, bark and leaf teas and extracts have been used to treat a wide range of diseases (Levy \& Carley 2012), but, along time, the fruit has gained great importance in the world market due to its sweet flavor and exotic aroma and colour (Gould \& Raga 2002).

Currently, Brazil is the third world producer of guava fruit, with Psidium guajava L. being the main commercial species. In 2017, about 461 thousand tonnes of this fruits of this species were produced in the country (IBGE 2019). Most of the country's production is designated to the food industry as a source of a variety of products for exports and internal market, such as natural and concentrated juices, frozen pulps, jams, jellies and deserts (Ramos 2008, Joseph \& Priya 2011, Manica et al. 2000).

Guava fruit is a source of a number of nutrients and bioactive compounds. Considering variations among cultivars, crops and edaphoclimatic conditions, on average, each 100 g contains: protein (0.1-2.5 g), carbohydrates (9.1$14.3 \mathrm{~g}$ ), fat (0.4-1.0 g), calcium (15-30 mg), iron (0.2$1 \mathrm{mg}$ ), phosphorus (26 mg), $\beta$ - and $\alpha$-carotenes (pro-vitamin A) (2,32 -2,84 mg), thiamine (0.03$0.06 \mathrm{mg}$ ) and ascorbic acid (70-300 mg) (USDA 2006). According to USDA, such ascorbic acid content can be up to six times the content in oranges in general (50-100 mg) (Correa et al. 2016). Additionally, guava contains soluble fibres (0.9-5.4 g) (Chiari et al. 2012). Among the main bioactive compounds in guava are carotenoid pigments, usually, but not always, related to the characteristic red colour of the fruit. In addition to $\beta$ - and $\alpha$-carotenes, guava is an important source of lycopene, with average concentrations $(5.4 \mathrm{~g} / 100 \mathrm{~g})$ two times higher than in tomatoes (2.54g/100g) (USDA 2006). The fruit also contains a number of phenolic compounds, including flavonoids (anthocyanins and quercetin) and tannins, triterpenes, saponins, and lectins, which contribute to guava's pulp bioactivity as a whole (Vindeloy 1977). Such variety of bioactive phytochemicals of different structures and types can be much more effective in disease 
prevention than when isolated as a result of synergistic or additive effects (Khoo et al. 2017).

Among the reported in vitro biopharmacological effects of guava fruit derived from the action of bioactive compounds is the antioxidative capacity, particularly as free-radical scavenger and as metal chelator, the capability of catalyzing the peroxidation of lipids (Rodriguez-Amaya 2001, Barreiros et al. 2006, Nascimento 2006). Despite the high antioxidative capacity of the fruit pulp, mainly the anti-carcinogenic effects of P. guajava leaves have been widely investigated in several studies and in a large number of cancer cell types (cervical, metastatic prostate, human mouth, murine leukemia and fibrosarcoma, human breast and human colon), while only a few studies have evaluated the anticarcinogenic effect of the pulp, especially in the case of breast cancer, with only one study which evaluated one type of guava (Correa et al. 2016). In addition to being considerably more palatable than the leaf tea, guava pulp can be used daily in tropical countries for cold juices preparation, which is important in countries where hot teas are not often consumed owning to the warm climate (Dantaset 2010).

One of the most important carotenoids with health beneficial effects present in guava fruits is lycopene. Numerous studies investigating the effects of lycopene on cancer cells have been recently published. Together, these studies highlight different mechanisms of action: modulation of intracellular communication of the gap junction; induction of apoptosis; modulation of cell cycle proteins; increase in BRCA1 and BRCA2 mRNA (onco-suppressor genes in breast cancer); alterations in the gene expression profile of various other molecular pathways such as apoptosis (p53 and Bax), cell communication, MAPK, cell cycle, xenobiotic metabolism, and fatty acid biosynthesis (Chalabi et al. 2006, Chalabi et al. 2007, King-Batoon et al. 2008, Takeshima et al. 2014, Peng et al. 2017, Dos Santos et al. 2018). Lycopene inhibits oxidative damage to DNA and suppresses cell growth by downregulating redox-sensitive signaling pathways, including MAPK and NF-kB pathways in human prostate cancer, breast cancer, and hepatocellular carcinoma cell lines (Park et al. 2005, Palozza et al. 2010, Assar et al. 2016). Previously, it has been showed that lycopene decreased the formation of $8-O H d G$, and suppressed the ROS-activated Jak1/Stat3 and Wnt/beta-catenin pathways in H. pylori-infected gastric epithelial cells (Jang et al. 2012, Park et al. 2019).

Among the cell lines used as models for the study of human breast cancer are MDAMB-435 and MCF-7. These cells have different characteristics. MDA-MB-435 cells do not express hormonal receptors (estrogen receptor - ER) and present high metastatic potential and high tumorigenicity. However, malignant tumors of patients with positive ER, that use estrogen as the main growth stimulant, correspond to about $80 \%$ of breast cancer cases (Alkhalaf \& El-mowafy 2003). Considering that blockage of ER may inhibit cell growth in the treatment of a malignant tumor sensitive to hormones, ER is the direct target of hormonal therapies for this type of cancer, and the occurrence or not of its expression is a decisive point in treatment. MCF7 epithelial cells present ER and progesterone receptor ( $P R)$, although they present low metastatic potential. Therefore, both cell lines are complementary in studies investigating the activity of extracts and compounds against human breast cancer (Weigel \& Dowsett 2010). Considering all the points aforementioned, this study aimed to evaluate the anticarcinogenic potential of guava cultivars pulp extracts in MDA-MB-435 and MCF-7 human breast cancer cells. 


\section{MATERIALS AND METHODS}

\section{Samples}

Ripe samples of guava (Psidium guajava L.) cultivars Pedro Sato (PS), Hitigio (HI) and Tsumori (TS) were obtained from the Fruit Project of the State Department of Agriculture and Livestock - SEAPEC-RJ in Cachoeira de Macacu, Rio de Janeiro, Brazil.

\section{Physicochemical characterization of guava cultivars extracts}

Physicochemical characterization, including determination of total sugars and ascorbic acid content, titratable acidity, and soluble solids (Brix), was performed according to the official methodologies of Adolfo Lutz Institute, Brazil (2005). The color of peels and pulps was measured by a Konica colorimeter (Minolta CM5), using the CIELAB scale $\left(L^{*}, a *, b *\right)$. Fruits weight and size were also recorded.

\section{Pulp extract preparation}

Guava pulp extracts (including seeds) were prepared according to Rocha Ribeiro et al. (2007), adapted. After testing five solvents and solvent mixtures, a mixture of acetone and water (70:30) was chosen to prepare the extract used in all assays. Fifty grams of guava pulp and seeds were mixed with $50 \mathrm{~mL}$ of the hydro-acetone mixture and the volume was made up to $100 \mathrm{~mL}$, with distilled water. The mixture was vortexed for approximately 3 mins, followed by water bath agitation for 60 mins at $25^{\circ} \mathrm{C}$. The solution was vacuum-filtered through a Whatman $n^{\circ} 1$ quantitative paper filter. Extracts were used immediately after they were prepared, except in the case of cell assays, for which they were lyophilized. Prior to lyophilisation, extracts were placed in a hot air balloon for solvent evaporation in a rotary evaporator (Terroni, Brazil) at $60^{\circ} \mathrm{C}$, for 2 hours. Following, the concentrated extracts were frozen at $-20^{\circ} \mathrm{C}$ for 24 hours and transferred to a lyophilizer (LD3000, Terroni, Brazil), where they remained for 72 hours to reach 3\% moisture. The final powdered pulp extract was packaged in amber vial and frozen at $-20{ }^{\circ} \mathrm{C}$, until cell assays.

\section{DPPH assay}

The evaluation of the antioxidant activity of guava extract by DPPH (2,2-diphenyl-1-picrilidrazil) radical assay was performed according to Brand-Williams et al. (1995). Aliquots of $0.5 \mathrm{~mL}$ of the fresh extracts were mixed with $2.5 \mathrm{~mL} \mathrm{DPPH}$ methanolic solution $(0.06 \mathrm{mM})$ and allowed to react for 1 hour in the dark. Measurements were performed at $515 \mathrm{~nm}$, using a spectrophotometer (Shimadzu UV-2700, Japan); the reduction in DPPH radical absorbance concentration caused by the extracts was compared to a trolox standard curve. Results were expressed as $\mu \mathrm{mol}$ trolox equivalents/g dry basis. Analyses were performed in triplicate.

\section{Ferric reducing antioxidant power (FRAP) assay}

The measurement of the antioxidant activity of the extracts by FRAP was performed according to Benzie \& Strain (1996). Aliquots of $2.7 \mathrm{~mL}$ of TPTZ reagent (ferric 2,4,6-tripyridyl-s-triazine) were mixed with $0.5 \mathrm{~mL}$ of sample extract (aliquots 5, 10, and $20 \mu \mathrm{L}$ ). After $30 \mathrm{~min}$ at 37 ${ }^{\circ} \mathrm{C}$, the absorbance was read at $595 \mathrm{~nm}$. The antioxidant capacity (FRAP) was expressed as Fe3+ equivalents ( $\mu \mathrm{mol}$ Fe3+/g dry basis).

\section{Trolox equivalent antioxidant capacity (TEAC/ ABTS) assay}

The complex TEAC.+ cation was prepared by mixing a TEAC stock solution (7 $\mathrm{mM}$ in water) with $2.45 \mathrm{mM}$ potassium persulfate. This mixture was allowed to rest for 16 hours at room temperature, until the reaction was completed and the absorbance was stable. The antioxidant capacity assay was carried out following the improved 
TEAC method as described by Re et al. (1999). The TEAC solution $(2.5 \mathrm{~mL}$ ) was added to the extract or the commercial reference antioxidant (trolox) and mixed thoroughly. Absorbance was recorded at $734 \mathrm{~nm}$, during $6 \mathrm{~min}$. Aliquots of 5 , 10 , and $20 \mathrm{~mL}$ of the extracts were tested and their volumes were completed to $0.5 \mathrm{~mL}$ with water. Results were expressed as $\mu \mathrm{mol}$ trolox/g dry basis.

\section{Carotenoids extraction and analysis}

Carotenoids profiles were determined by liquid chromatography according to Pacheco et al. (2014), using a Waters TM HPLC system, controlled by the Empower software program with photodiode array detector (PDA). Carotenoid separation was obtained in a C30 column (S-3 Carotenoid, $4.6 \mathrm{~mm} \times 250 \mathrm{~mm}, \mathrm{YCMTM}$ ) at $33^{\circ} \mathrm{C}$, by a gradient elution of methanol and methyl tert-butyl ether. The elution started with a mix of $80 \%$ methanol and $20 \%$ methyl tert-butyl ether. At $0.5 \mathrm{~min}$ the concentration of ether was increased to $25 \%$, at $15.00 \mathrm{~min}$ to $85 \%$ and at 15.05 to $90 \%$ ether. The concentration of ether was maintained at $90 \%$ until $16.50 \mathrm{~min}$ and then, at $16.55 \mathrm{~min}$, it returned to the initial condition (20\%), remaining constant up to 28 min point. Flow rate was $0.8 \mathrm{~mL} / \mathrm{min}$ and running time was $28 \mathrm{~min}$. Sample injection volume was 15 $\mu \mathrm{L}$. Carotenoids were identified based on their retention times and UV/Vis absorption spectra, compared to the standard retention times and UV/Vis absorption spectra of each carotenoid.

\section{Total phenolics assay}

The total phenolic content of the extracts was determined according to the Folin-Ciocalteu method, as described by Singleton and Rossi (1965), with minor modifications. Aliquots of $0.5 \mathrm{~mL}$ of the extracts were added to $2.5 \mathrm{~mL}$ of Folin-Ciocalteu reagent and $2.0 \mathrm{~mL}$ of $4 \%$ sodium carbonate solution, and the mixture was put to rest for 2 hours in the dark. Measurements were performed at $760 \mathrm{~nm}$ in triplicate, applying a Turner 340 spectrophotometer. Gallic acid (range of $0-100 \mathrm{mg} / \mathrm{mL}$ ) was used to produce a calibration curve. The concentration of total phenolic compounds in the extract was expressed as gallic acid equivalents, reflecting the total phenolic content in $\mathrm{mg} / 100 \mathrm{~g}$ of sample material.

\section{Cell culture and treatment protocol}

Cell lines certified for identity and quality (INMETRO Rio de Janeiro, RJ, Brazil) were obtained from the Rio de Janeiro Cell Bank. Human breast carcinoma cell lines (MDA-MB-435 and MCF-7) were plated separately in $25 \mathrm{~cm} 2$ tissue culture flasks (5.0 × 106 cells/flask) and maintained routinely in Dulbecco's Modified eagle's medium high glucose (DMEM), supplemented with $10 \%$ Fetal Bovine Serum (FBS) and 1\% penicillin (PS), $\mathrm{pH} 7.4$, under 5\% CO2 atmosphere. Stock flasks were grown to $70 \%$ confluence and subcultured routinely. Medium renewal was executed 3 times per week. For each experiment, cells were seeded at $3.5 \times 105$ cells/cm2 and $2 \times 104$ cells/cm2 densities in 6-well plates and 96well plates for cell cycle and cell proliferation analyses, respectively. After $24 \mathrm{~h}$, the medium was removed and cells were treated with nine increasing concentrations of guava extracts from 15 to $5000 \mu \mathrm{g} / \mathrm{mL}$, dissolved in DMEM. The controls, DMEM and DMEM + negative controls (hydro acetone solutions) were included on each plate. Cells were then incubated for 24 and 48 hours.

\section{Cell viability assay}

Cell viability was monitored through MTT assay (Amresco,Solon,OH).MTT(3-(4,5-dimethylthiazol2-yl)-2,5-diphenyltetrazolium bromide) is a pale yellow substrate that is reduced by living cells to yield a dark blue formazan product. 
Exponentially growing cells were adjusted to 2.0 $\times 104 / \mathrm{cm} 2$ with DMEM, plated in 96-well plates (Corning, Tewksbury, MA) at $200 \mathrm{~mL} /$ well and incubated for 24 hours, according to the routine procedure. The cells were then incubated with guava extracts for 24 and 48 hours. Each well was also incubated with MTT $(10 \mu \mathrm{L} /$ well; $5 \mathrm{mg} / \mathrm{mL})$ for 4 hours. Following, $85 \mathrm{~mL} /$ well of the liquid was removed and $50 \mu \mathrm{L} /$ well of sodium dodecyl sulfate was added to dissolve the solid residue. Finally, the absorbance was measured using a microplate reader (POLARIS, CELER) at $570 \mathrm{~nm}$. The cell proliferation inhibition rate (CPIR) was calculated as follows:

CPIR = (1 - average value of experimental group/average value of control group) $\times 100 \%$.

\section{Cell cycle analysis}

Cells were briefly rinsed with calcium and magnesium-free phosphate-buffered saline and detached with trypsin at room temperature. After centrifugation, cells were washed twice with phosphate-buffered saline and $1 \times 106$ cells were resuspended in $1.0 \mathrm{~mL}$ of ice-cold Vindelov solution (Vindelov 1977), containing 0.1\% Triton $\mathrm{X}-100,0.1 \%$ citrate buffer and $0.1 \mathrm{mg} / \mathrm{mL}$ RNase, and $50 \mathrm{mg} / \mathrm{mL}$ propidium iodide (Sigma Chemical Co., St. Louis, MO). After 15 min incubation, the cell suspension was analyzed for DNA content by flow cytometry using a FACS Calibur flow cytometer (Becton Dickinson, Mountain View, CA). The relative proportions of cells with DNA content diploid $G_{0}-G_{1}$ phase $(2 n)$, S phase $(>2 n$ but $<4 n$ ) and $G_{2} / M$ phase ( $4 n$ ) were acquired and analyzed using CellQuest and WinMDI 2.9, respectively. The percentage of cell population at a particular stage was estimated with EXPO32 V1.2 Analysis software. The cell dissociation procedure does not affect fluorescence under the experimental conditions that were used in this study or in any other studies as far as the authors know. Nuclei of viable cells were gated according to FL-2W x FL2-A relation (Vindeloy 1977).

\section{Apoptosis assay}

In order to measure the apoptosis rate, the studied cells were resuspended in $400 \mu \mathrm{L}$ of binding buffer containing $5 \mu \mathrm{L}$ of annexin V FITC and $5 \mu$ Lpropidium iodide (Apoptosis Detection Kit II, BDBiosciences) for $15 \mathrm{~min}$ at room temperature. Annexin $\mathrm{V}$ binding was evaluated by flow cytometry (FACS calibur, BD Biosciences), and after acquisition of 30,000 events, data were analyzed in CellQuest and FlowJo software.

\section{Statistical analysis}

Results are presented as mean with the corresponding standard deviation of three independent experiments performed in triplicate $(n=9)$. Data from cell viability test, cell cycle and apoptosis essays were analyzed using the statistics softwares GraphPad Prism (version 5.04, San Diego, CA), Statistica (version 7.0, StatSoft Inc., Tulsa, OK), and Minitab 17 Statistical Software (version 17, State College, PA: Minitab, Inc.). One-way analysis of variance (ANOVA) test followed by Tukey's test were used to test cell viability, cell cycle, and apoptosis. Differences were considered at a significance level of $5 \%(p \leq 0.05)$.

\section{RESULTS}

\section{Physicochemical characterization of guava cultivars extracts}

The physicochemical parameters of peels and pulps of guava cultivars are presented in Table I. Regarding peel colorimetric results, PS and $\mathrm{HI}$ cultivars presented the highest mean values for brightness $\left(L^{*}\right)$, TS presented the least greenish shade $\left(a^{*}\right)$, and PS and $H I$ the most intense yellow shade $\left(b^{*}\right)$. HI presented predominance of green $\left(-a^{\star}\right)$. Regarding the pulps, there was 
Table I. Physical and chemical characterization of guava cultivar extracts. Significant differences are indicated as a, $\mathrm{b}$ and $\mathrm{c}$.

\begin{tabular}{|c|c|c|c|c|c|c|c|}
\hline \multicolumn{4}{|c|}{ Physical parametres } & \multicolumn{4}{|c|}{ Chemical and antioxidant parameters } \\
\hline & PS & TS & HI & & PS & TS & HI \\
\hline Weight (g) & $220.16 \pm 40.08^{\mathrm{a}}$ & $297.52 \pm 79.06^{c}$ & $158.16 \pm 15.43^{b}$ & Total sugar (g\%) & $12.33 \pm 0.45^{\mathrm{a}}$ & $13.12 \pm 1.73^{\mathrm{a}}$ & $10.95 \pm .1 .22^{\mathrm{a}}$ \\
\hline $\begin{array}{l}\text { Dimension } \\
\quad(\mathrm{cm})\end{array}$ & $8.34 \pm 0.51^{\mathrm{a}}$ & $8.78 \pm 1.01^{c}$ & $7.27 \pm 0.40^{b}$ & $\begin{array}{l}\text { Soluble Solids } \\
\left.\text { ( }{ }^{\circ} \text { Brix }\right)\end{array}$ & $10.11 \pm 0.02^{\mathrm{a}}$ & $11.08 \pm 0.01^{\mathrm{a}}$ & $9.47 \pm 0.01^{a}$ \\
\hline $\begin{array}{l}\text { CIELAB scale } \\
\text { (peel) }\end{array}$ & & & & $\begin{array}{c}\text { Titratable } \\
\text { Acidity (g\%) }\end{array}$ & $0.36 \pm 0.01^{\mathrm{a}}$ & $0.47 \pm 0.03^{b}$ & $0.39 \pm 0.01^{a}$ \\
\hline $\mathbf{L}^{*}$ & $65.56 \pm 1.72^{\mathrm{a}}$ & $55.49 \pm 10.06^{b}$ & $59.90 \pm 3.71^{a . b}$ & $\begin{array}{l}\text { Ascorbic acid } \\
\text { (mg\%) }\end{array}$ & $81.81 \pm 2.04^{\mathrm{a}}$ & $80.36 \pm 1.87^{\mathrm{a}}$ & $79.35 \pm 3.30^{\mathrm{a}}$ \\
\hline$a^{*}$ & $-0.40 \pm 2.22^{b}$ & $0.90 \pm 4.59^{b}$ & $-5.18 \pm 2.32^{\mathrm{a}}$ & $\begin{array}{l}\text { Lycopene } \\
\text { (mg/100g) }\end{array}$ & $5.43 \pm 0.32^{a}$ & $2.34 \pm 0.43^{c}$ & $3.21 \pm 0.85^{b}$ \\
\hline $\mathbf{b}^{*}$ & $42.30 \pm 3.16^{\mathrm{a}}$ & $28.59 \pm 9.12^{b}$ & $39.59 \pm 3.08^{a}$ & $\begin{array}{c}\beta \text {-carotene } \\
\text { (mg/100g) }\end{array}$ & $0.13 \pm 0.08^{\mathrm{a}}$ & $1.54 \pm 0.98^{c}$ & $0.50 \pm 0.12^{b}$ \\
\hline $\begin{array}{l}\text { CIELAB scale } \\
\text { (pulp) }\end{array}$ & & & & $\begin{array}{l}\text { Total phenolics } \\
\text { (mg GAE/100 g) }\end{array}$ & $200.88 \pm 1.44^{a}$ & $125.56 \pm 8.74^{c}$ & $156.64 \pm 1.14^{b}$ \\
\hline $\mathbf{L}^{*}$ & $55.21 \pm 1.68^{\mathrm{a}}$ & $61.83 \pm 4.59^{\mathrm{a}}$ & $58.53 \pm 1.72^{\mathrm{a}}$ & $\begin{array}{c}\text { DPPH (\% } \\
\text { reduction) }\end{array}$ & $76.96 \pm 2.35$ & $56.84 \pm 1.04$ & $55.91 \pm 0.80$ \\
\hline$a^{*}$ & $32.25 \pm 1.17^{\mathrm{a}}$ & $22.45 \pm 1.97^{b}$ & $30.99 \pm 1.24^{a}$ & $\begin{array}{c}\text { ABTS ( } \mu \text { mol } \\
\text { Trolox/g) }\end{array}$ & $208.05 \pm 9.69$ & $151.07 \pm 1.93$ & $129.91 \pm 3.04$ \\
\hline $\mathbf{b}^{*}$ & $21.69 \pm 2.02^{\mathrm{a}}$ & $21.01 \pm 1.16^{\mathrm{a}}$ & $21.81 \pm 0.51^{\mathrm{a}}$ & $\begin{array}{l}\text { FRAP ( } \mu \mathrm{mol} \\
\text { ferrous } \\
\text { sulfate/g) }\end{array}$ & $41.84 \pm 0.84$ & $30.41 \pm 0.46$ & $23.73 \pm 0.20$ \\
\hline
\end{tabular}

no difference in brightness among cultivars. PS and $\mathrm{HI}$ presented more intense red shade, while TS pulp was paler. No significant difference was observed in $b$ * scale, meaning that pulps presented similar shade of yellow.

The three cultivars presented similar soluble solids, sugar and ascorbic acid contents (Table I). The most acidic cultivar was TS, while the remaining two presented similar acidity values. The three cultivars pulp extracts presented different concentrations of carotenoids. PS presented the highest concentration of lycopene, which was about two times higher than in TS and one and a half time higher than in HI cultivar. For $\beta$-carotene, the highest concentration was observed in TS, which was three times higher than in $\mathrm{HI}$ and eleven times higher than in PS. On the other hand, PS contained the highest concentration of phenolic compounds (which includes anthocyanins), followed by $\mathrm{HI}$ and TS.

\section{Antioxidant activity (AA)}

PS cultivar presented the highest AA values when evaluated by all three in vitro methods (DPPH, FRAP and TEAC) (Table I). A positive correlation between ascorbic acid content and FRAP results ( $r=0.999 ; p=0.03$ ) was observed. Other correlations were not relevant (data not shown).

\section{Cell viability by MTT assay}

In order to assess the antitumor effect of guava extracts, two breast carcinoma cell lines were used in this assay (MDA-MB-435 and MCF-7). Guava extracts changed MDA-MB-435 cells growth profile after 24 and 48 hours incubation (Figure 1). After 24 hours incubation with guava 
pulp extracts, PS cultivar presented the highest percentage of reduction in cell viability $(45 \%$, compared to untreated cells), followed by $\mathrm{HI}$. Cells treated with TS pulp extract did not grow differently from control (untreated) cells after 24 hours incubation. However, after 48 hours, all guava cultivars' extracts promoted reduction in MDA-MB-435 cells viability. TS extract showed the greatest reduction in cell viability, in concentrations from 15 to $5000 \mu \mathrm{g} / \mathrm{mL}$, with average inhibition of 70\% compared to negative control. Results from PS and HI cultivars showed no statistical difference in the concentrations tested (from 15 to $5000 \mu \mathrm{g} / \mathrm{mL}$ ), with maximum reductions of $57 \%$ and $44 \%$ in these two concentrations for PS and $\mathrm{HI}$, respectively.

ст

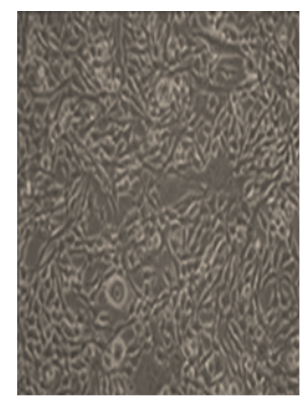

24h

$48 \mathrm{~h}$
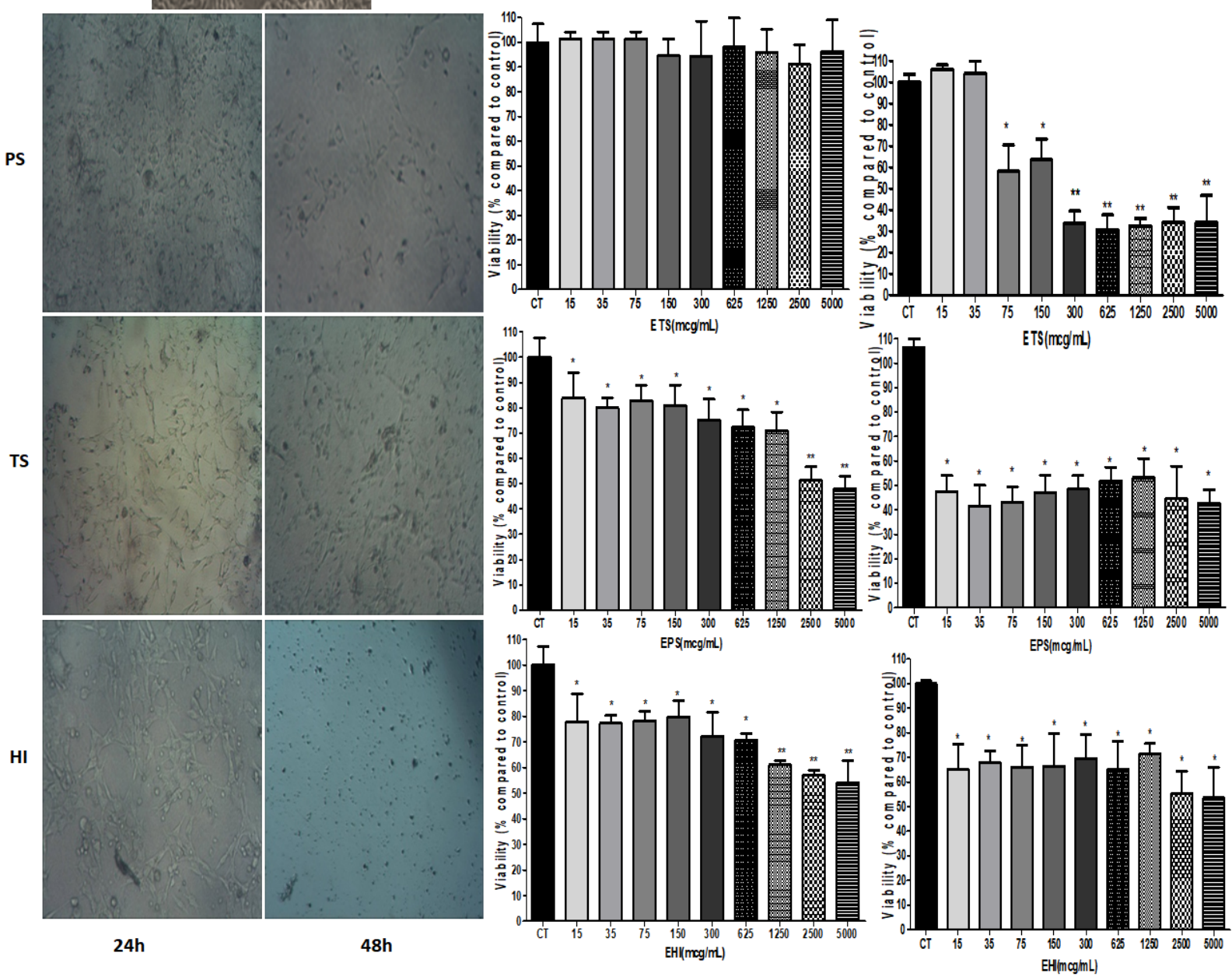

Figure 1. Effect of Tsumori (TS), Pedro Sato (PS), and Hitígio (HI) guava extracts (15-5000 $\mu \mathrm{g} / \mathrm{mL}$ ) on MDA-MB -435 cells viability after 24 and 48 hrs treatment. Results were compared by One- way ANOVA test and Tukey test (* $\left.\mathrm{p}<0.05 ;{ }^{* *} \mathrm{p}<0.01\right) . \mathrm{CT}=$ Results of untreated (CT) and treated cells. 


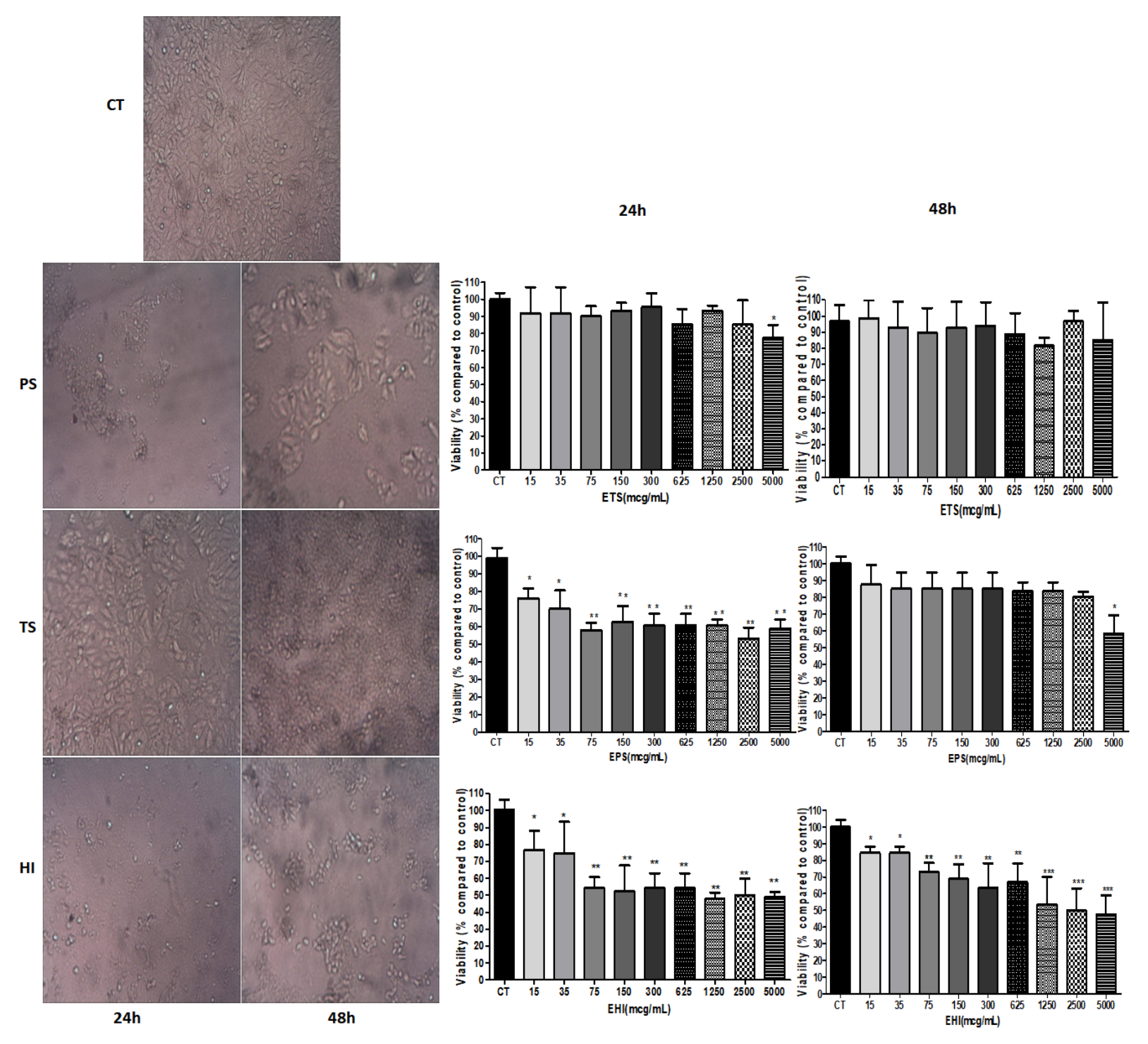

Figure 2. Effect of 24 and 48 hrs incubation of MCF-7 cells with Tsumori (TS), Pedro Sato (PS) and Hitígio (HI) guava cultivar extracts $(15-5000 \mu \mathrm{g} / \mathrm{mL})$ on cells viability. Results were compared by One- way ANOVA followed by Tukey test Significant differences are indicated as * $p<0.05$ and ${ }^{* *} p<0.01$.

Guava extracts also caused reduction in MCF7 cell viability after 24 and 48 hours treatment when compared to control group (Figure 2). After 24 hours treatment, PS and HI cultivars showed $50 \%$ reduction in cell viability, in concentrations ranging from 75 to $5000 \mu \mathrm{g} / \mathrm{mL}$, while TS extract only reduced $10 \%$ in the highest concentration. After 48 hours treatment, TS cultivar did not affect cell viability, while PS at $5000 \mu \mathrm{g} / \mathrm{mL}$ reduced $40 \%$ compared to control. $\mathrm{HI}$ extract presented similar behaviour after 48 hours treatments compared to that observed after 24 hours treatment. Therefore for other assays, $24 \mathrm{~h}$ incubation was considered.

\section{Effect of guava cultivars extracts on cell cycle}

In order to assess the effect of guava pulp extracts on cell cycle, based on MTT assay results for human breast carcinoma cell lines, MDA-MB-435 cells were incubated with the 

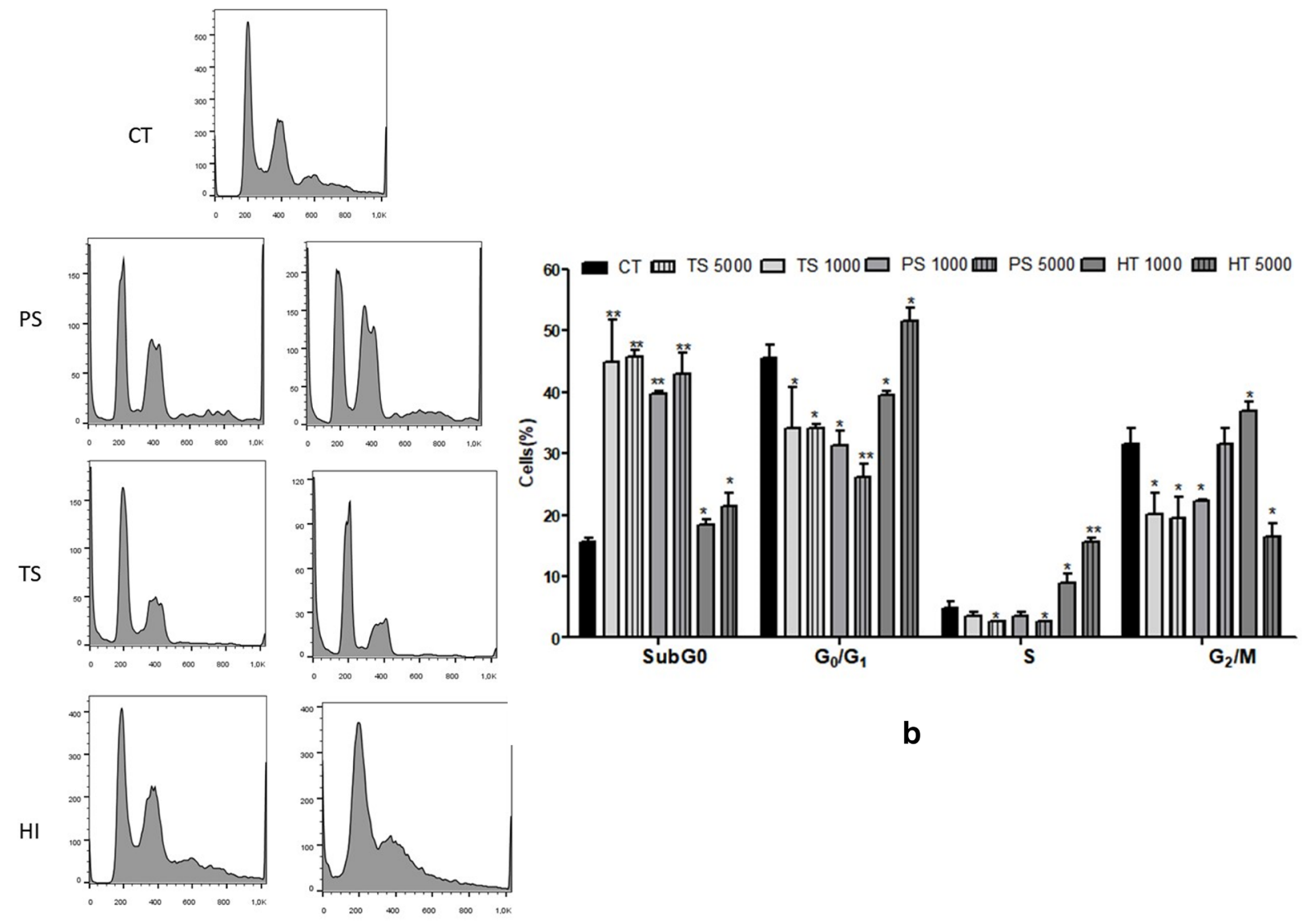

b

$1000 \mu \mathrm{g} / \mathrm{mL}$

\section{a}

$5000 \mu \mathrm{g} / \mathrm{mL}$

Figure 3. Effect of $48 \mathrm{~h}$ incubation of MDA-MB 435 cells with 1000 and $5000 \mu \mathrm{g} / \mathrm{mL}$ Pedro Sato (PS), Tsumori (TS) and Hitígio (HI) guava cultivar extracts on cell cycle progression. Cell cycle phases are illustrated in (a). Quantitative results are shown in graph (b). Results are expressed as mean \pm standard deviation of two experiments. Significant differences between untreated (CT) and treated cells were compared by One- way ANOVA followed byTukey test Significant differences are indicated as * $p<0.05$ and ** $p<0.01$.

extracts for 48 hours (Figure 3 ) and MCF-7 cells for 24 hours (Figure 4), with two concentrations of each of the three guava pulp extracts (1000 $\mu \mathrm{g} / \mathrm{mL}$ and $5000 \mu \mathrm{g} / \mathrm{mL}$ ), followed by evaluation of the percentage of viable cells in the different cell cycle phases. Treatment of MDA-MB-435 cells with PS and TS extracts caused an increase in the percentage of cells in the $G_{0}$ subphase, followed by a reduction of cells in $G_{0} / G_{1}$ and $\mathrm{G}_{2} / \mathrm{M}$ phases. There was also a reduction of cells in the $\mathrm{S}$ phase at the highest concentration $(5000 \mu \mathrm{g} / \mathrm{mL})$ for all cultivars. In MCF-7 cell line, after 24 hours treatment with PS, HI, and
TS extracts, a reduction in proliferation was observed. All cultivars increased the percentage of cells in the $G_{0}$ sub-phase ( $p=0.01$ ) and caused a reduction of cells in the $G_{0} / G_{1}$ phase, when compared to the untreated cells, except for $\mathrm{HI}$ cultivar in the lowest concentration $(1000 \mu \mathrm{g} /$ $\mathrm{mL}$ ). It was still possible to see a reduction of cells in the $S$ phase after the treatment of guava extracts, except for TS and PS cultivars at 1000 $\mu \mathrm{g} / \mathrm{mL}$. Additionally, both concentrations of $\mathrm{HI}$ $(1000 \mu \mathrm{g} / \mathrm{mL}$ and $5000 \mu \mathrm{g} / \mathrm{mL})$ and the highest concentration of PS $(5000 \mu \mathrm{g} / \mathrm{mL})$ produced a decrease in cells count in the $G_{2} / M$ phase ( $p$ 
$=0.01)$. An increased number of cells in $G_{2} / M$ phase was also observed when PS was tested at $1000 \mu \mathrm{g} / \mathrm{mL}$.

\section{Effect of guava cultivars extracts on apoptosis}

Considering the cell cycle results, MDA-MB-435 cells and MCF-7 cells were treated with guava cultivars extracts $(1000 \mu \mathrm{g} / \mathrm{mL}$ and $5000 \mu \mathrm{g} /$ $\mathrm{mL}$ ) for 48 hours and for 24 hours, respectively, for apoptosis rate evaluation. Results are presented in Table II and in Figure 5. In MDAMB-435 cells, 48 hours-treatments with all cultivars (in both concentrations) caused a relative increase in apoptotic cells of 6 to 8 fold-compared to control. PS cultivar showed the highest reduction in viable cells (54.6\%) at $1000 \mu \mathrm{g} / \mathrm{mL}$, while the highest reduction of $\mathrm{HI}$ cultivar (61.2\%) occurred at $5000 \mu \mathrm{g} / \mathrm{mL}$ (Table II). In MCF-7 cells, which offer greater resistance to chemotherapy, 24h-treatment with PS and $\mathrm{HI}$ cultivars caused relative decrease in viable cells, in a similar magnitude $(4.1 \%$ and $21.4 \%$ at $1000 \mathrm{\mu g} / \mathrm{mL}$, respectively, and $11.7 \%$ and $9.1 \%$ at $5000 \mu \mathrm{g} / \mathrm{mL}$, respectively. Also, both cultivars showed a relative increase in the percentage of early apoptosis $(80.4 \%$ at $1000 \mu \mathrm{g} / \mathrm{mL}$ and $90.2 \%$

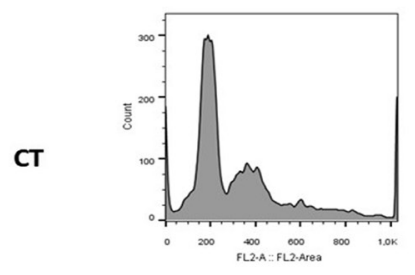

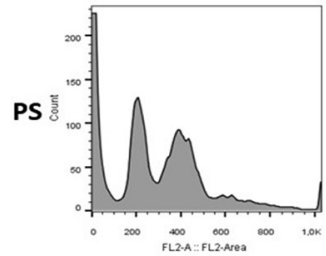

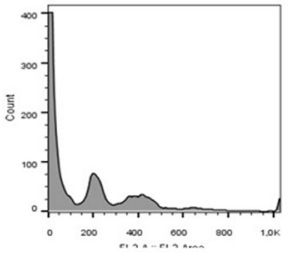

TS
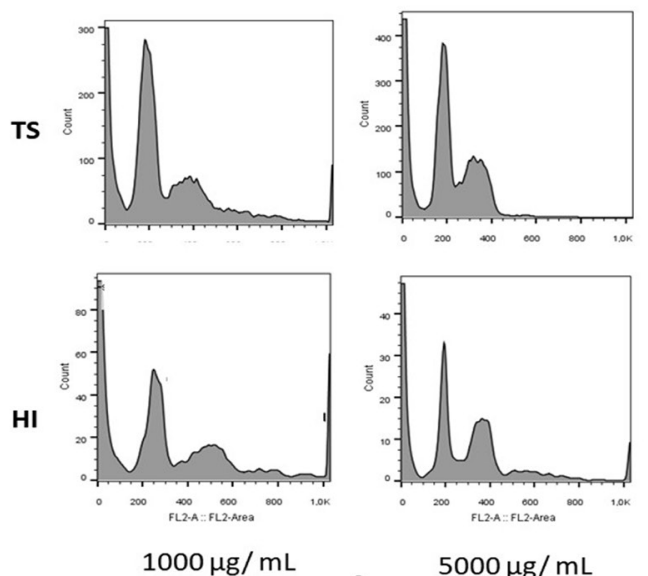

$1000 \mu \mathrm{g} / \mathrm{mL}$

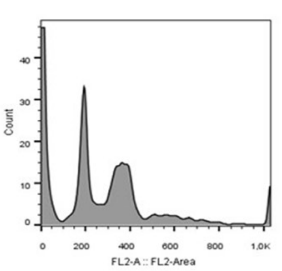

a

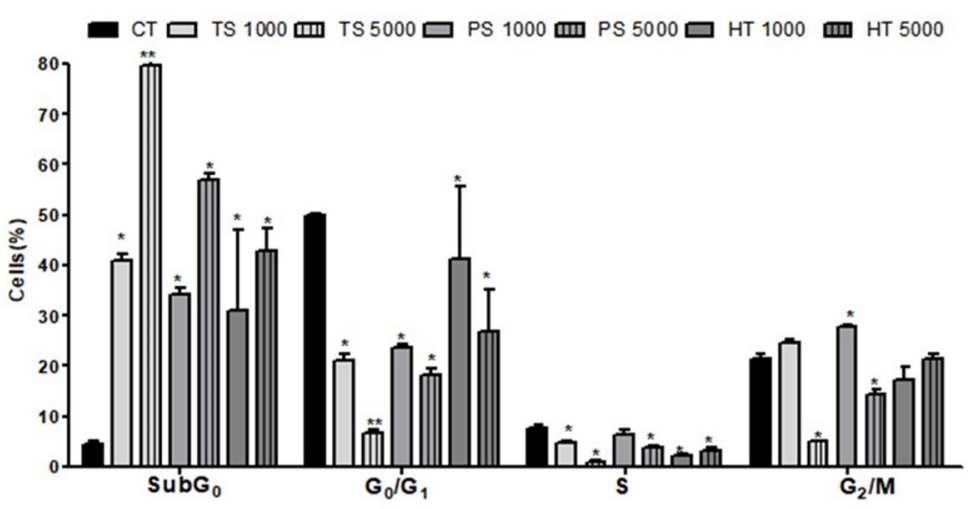

b

Figure 4. Effect of 24hrs-incubation of MCF-7 cells with 1000 and $5000 \mu \mathrm{g} / \mathrm{mL}$ of Pedro Sato (PS), Tsumori (TS) and Hitígio (HI) guava cultivars extracts on cell cycle progression. Cell cycle phases are illustrated in (a). Quantitative results are shown in graph (b). Results are expressed as mean \pm standard deviation of two experiments. Results of untreated (CT) and treated cells were compared by One- way ANOVA followed by Tukey test. Significant differences are indicated as ${ }^{*} \mathrm{p}<0.05$ and ${ }^{* *} \mathrm{p}<0.01$. 
Table II. Effect of Pedro Sato(PS), Tsumori(TS) and Hitigio(HI) guava cultivars extracts on death process stages in MDA-MB-435 and MCF-7. Significant differences are indicated as *, ${ }^{* *} \mathrm{p}<0.01,{ }^{* * *} \mathrm{p}<0.001$.

\begin{tabular}{|c|c|c|c|c|c|c|c|}
\hline \multirow[b]{2}{*}{$\begin{array}{c}\text { Guava } \\
\text { Cultivars } \\
\text { extract }\end{array}$} & \multirow[b]{2}{*}{ Stages of cell death } & \multicolumn{3}{|c|}{ MDA-MB 435} & \multicolumn{3}{|c|}{ MCF-7 } \\
\hline & & Ст & $1000 \mu \mathrm{g} / \mathrm{mL}$ & $5000 \mu \mathrm{g} / \mathrm{mL}$ & CT & $\underset{\mathrm{mL}}{1000 \mu \mathrm{g} /}$ & $5000 \mu \mathrm{g} / \mathrm{mL}$ \\
\hline \multirow{4}{*}{ PS } & $\begin{array}{c}\text { Viable cells } \\
\text { (Annexin V- PI-) }\end{array}$ & $86.03 \pm 3.21$ & $39.10 \pm 4.10^{* \star \star}$ & $44.25 \pm 1.77^{\star \star}$ & $93.60 \pm 1.34$ & $89.75 \pm 1.64^{*}$ & $73.55 \pm 10.92^{* \star}$ \\
\hline & $\begin{array}{l}\text { Early apoptosis } \\
(\text { Annexin } \mathrm{V}+\mathrm{Pl}-\text { ) }\end{array}$ & $3.77 \pm 1.88$ & $46.25 \pm 0.21^{* \star \star}$ & $17.85 \pm 0.96^{\star \star \star}$ & $0.84 \pm 0.78$ & $4.29 \pm 0.39 * *$ & $8.58 \pm 3.69^{* \star \star}$ \\
\hline & $\begin{array}{l}\text { Late apoptosis } \\
(\text { Annexin } \mathrm{V}+\mathrm{Pl}+)\end{array}$ & $3.81 \pm 0.99$ & $16.75 \pm 0.35^{\star * *}$ & $36.15 \pm 1.20^{\star \star \star}$ & $0.25 \pm 0.57$ & $2.93 \pm 0.11^{*}$ & $3.90 \pm 0.86^{*}$ \\
\hline & $\begin{array}{l}\text { Non-apoptotic cells } \\
\text { (Annexin } \mathrm{V}-\mathrm{PI}+\text { ) }\end{array}$ & $6.42 \pm 1.52$ & $0.61 \pm 0.16^{\star \star \star}$ & $2.25 \pm 1.06^{* *}$ & $4.29 \pm 1.13$ & $5.15 \pm 1.90$ & $5.36 \pm 0.78$ \\
\hline \multirow{4}{*}{ TS } & $\begin{array}{c}\text { Viablecells } \\
\text { (Annexin V- PI-) }\end{array}$ & $82.60 \pm 4.81$ & $39.10 \pm 4.20^{* *}$ & $44.25 \pm 1.77^{\star \star}$ & $91.85 \pm 2.19$ & $90.30 \pm 1.45$ & $90.35 \pm 1.34$ \\
\hline & $\begin{array}{l}\text { Early apoptosis } \\
\text { (Annexin } \mathrm{V}+\mathrm{Pl}-\text { ) }\end{array}$ & $3.27 \pm 0.76$ & $17.58 \pm 2.39 * * *$ & $2.20 \pm 1.70$ & $2.51 \pm 0.78$ & $1.77 \pm 0.39$ & $0.94 \pm 0.34^{*}$ \\
\hline & $\begin{array}{l}\text { Late apoptosis } \\
(\text { Annexin } \mathrm{V}+\mathrm{PI}+\text { ) }\end{array}$ & $5.05 \pm 1.80$ & $16.75 \pm 2.33^{* * \star}$ & $36.15 \pm 1.20^{\star \star \star}$ & $3.57 \pm 0.85$ & $2.38 \pm 0.30$ & $2.87 \pm 1.90$ \\
\hline & $\begin{array}{l}\text { Non-apoptotic cells } \\
(\text { Annexin } \mathrm{V}-\mathrm{Pl}+\text { ) }\end{array}$ & $9.06 \pm 3.73$ & $1.03 \pm 0.63^{\star * *}$ & $2.25 \pm 1.06^{* *}$ & $4.04 \pm 1.06$ & $7.15 \pm 1.90^{*}$ & $8.87 \pm 2.60 *$ \\
\hline \multirow{4}{*}{ HI } & $\begin{array}{c}\text { Viable cells } \\
\text { (Anexin V-PI-) }\end{array}$ & $80.28 \pm 1.35$ & $47.45 \pm 9.00^{\star *}$ & $31.15 \pm 1.83^{* * *}$ & $92.10 \pm 4.12$ & $81.35 \pm 4.74^{*}$ & $83.70 \pm 2.38^{*}$ \\
\hline & $\begin{array}{l}\text { Early apoptosis } \\
(\text { Annexin } \mathrm{V}+\mathrm{Pl}-)\end{array}$ & $2.73 \pm 1.74$ & $42.55 \pm 19.16^{\star *}$ & $1.30 \pm 1.00$ & $3.78 \pm 1.47$ & $7.62 \pm 2.52^{\star *}$ & $8.24 \pm 0.72^{\star \star}$ \\
\hline & $\begin{array}{l}\text { Late apoptosis } \\
(\text { Anexin } \mathrm{V}+\mathrm{PI}+)\end{array}$ & $6.32 \pm 3.20$ & $9.78 \pm 2.01$ & $50.55 \pm 0.78^{* * *}$ & $2.42 \pm 2.62$ & $7.98 \pm 0.57^{\star \star}$ & $6.36 \pm 1.25^{\star \star}$ \\
\hline & $\begin{array}{l}\text { Non-apoptotic cells } \\
(\text { Annexin V-PI+) }\end{array}$ & $11.72 \pm 2.98$ & $0.30 \pm 0.16^{* \star *}$ & $13.55 \pm 3.64$ & $3.71 \pm 1.21$ & $2.08 \pm 1.64$ & $2.94 \pm 0.98$ \\
\hline
\end{tabular}

at $5000 \mu \mathrm{g} / \mathrm{mL}$ for PS, and $50.4 \%$ and $54.1 \%$, respectively, for $\mathrm{HI})$ and late apoptosis (91.5\% and $93.6 \%$, respectively, for PS, and $69.7 \%$ and $62.0 \%$, respectively, for $\mathrm{HI}$ ). Twenty four hourtreatment with TS did not cause significant changes in apoptosis.

\section{DISCUSSION}

The colorimetric parameters were measured in order to correlate them with the content of bioactive compounds, mainly carotenoids and total phenolic compounds (used in this study to reflect the content of anthocyanins, the main polyphenols in guava), considering that the intense red colour of guava pulp has been reported to be associated with high contents of these compounds in addition to some carotenoids (Kuskoski et al. 2005). Additionally, we aimed to associate the content of such compounds with the bioactivity results for the different cultivars. The bright pinkish-red shade of PS and HI, and the white-yellowish shade of TS (known as "white" guava), were expected, since they are characteristic of the respective cultivars. Corroborating these findings, in the present study, PS pulp, which presented the 


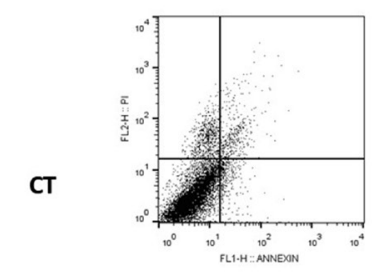

PS
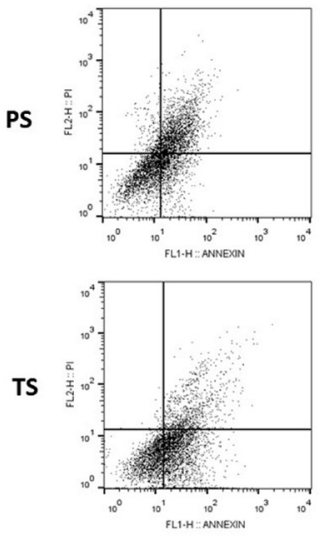

HI

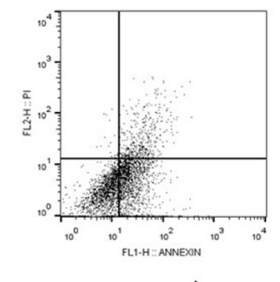

$1000 \mu \mathrm{g} / \mathrm{mL}$
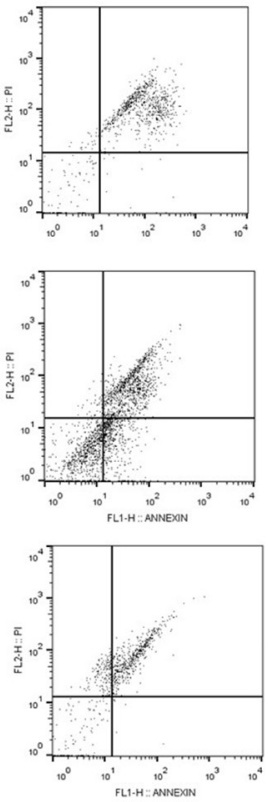

$5000 \mu \mathrm{g} / \mathrm{mL}$

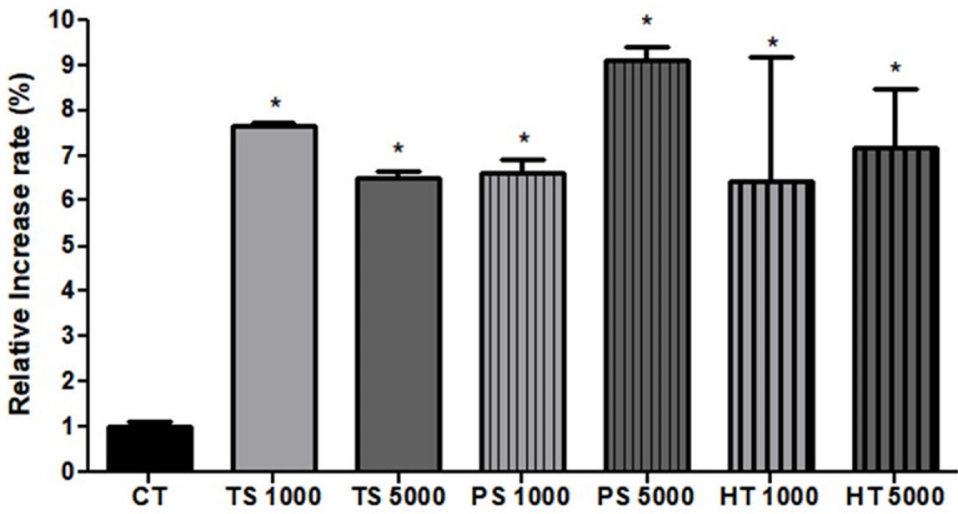

b

Figure 5. Increased relative rate of apoptosis in MDA-MB 435(a and b) treated for $48 \mathrm{hrs}$, with 1000 and $5000 \mu \mathrm{g} /$ $\mathrm{mL}$ of Pedro Sato (PS), Tsumori (TS) and Hitigio (HI) guava cultivars extracts. Results were compared by One- way ANOVA followed by Tukey test for significance (* $p<0.05 ; p<0.01)$. CT $=$ Results of untreated (CT) and treated cells.

best results for all performed essays, also presented the highest content of total phenolic compounds and lycopene. Among anthocyanins, cyanidin 3-glycoside has been reported to have great relevance for red guava, corresponding to about $50 \%$ of total anthocyanins (Kuskoski et al. 2006). Additional phenolic compounds identified in different types of guava are derivatives of kaempferol and quercetin, esculin, sinapoylquinic acid, among other minor compounds (Chiari-Andréo 2017). Amid carotenoids, $\beta$-Cryptoxanthin and lycopene are of great importance in guava pulp (Kuskoski et al. 2006, Nora et al. 2014). The highest content of $\beta$-carotene observed in the whiteyellowish cultivar (TS) and lower in red cultivars indicate that this carotenoid pigment does not contribute importantly to guava red color, which was surprising, since its content in guava pulp is comparable to that in papaya pulp (Ribeiro el at. 2014). This occurs possibly either because in guava pulp $\beta$-carotene is stored and hidden in a cell compartment or because it is masked by the presence of other pigment such as chlorophyll (Chitarra \& Chitarra 2005). On the other hand, considering the highest content of lycopene in PS cultivar, this carotenoid compound seemed to have contributed to its intense red color, together with anthocyanins, corroborating literature data (Kuskoski et al. 2005).

Regarding the antioxidative capacity, in view of the fact that no single assay can reflect 
the exact "total antioxidative capacity" of a food matrix owing to the different nature of its bioactive compounds, we used methods based on different mechanisms of action (Hou et al. 2004). This is especially important for guava, which is rich in both lipophilic and hydrophilic bioactive compounds that act through different mechanisms to promote antioxidant activity (Huang et al. 2005, Martínez et al. 2012). As aforementioned, the fact that PS cultivar presented the highest antioxidant capacity measured by all tested methods is in line with its higher content of phenolic compounds, which present medium hydrophilicity, and carotenoid pigments, mainly lycopene, which is part of the lipid fraction (Dávalos et al. 2005, Stahl \& Sies 2005). Some naturally occurring phenolic compounds in guava, as well as analogs, are known to display a wide variety of biological functions, including anti-inflammatory and antioxidant activities, which are closely related to modulation of carcinogenesis. (Stahl \& Sies 2005). Phenolic compounds work as radical hijackers and sometimes as transition metal chelation, acting both at the initiation and propagation stages of the oxidative process reaction, by donating hydrogen atoms to these molecules and disrupting the chain reaction (Reische et al. 2002, Fu et al. 2011).

The antioxidant property of licopene and other carotenoids also stems from their ability to perform free radicals scavenging (Caetano et al. 2011). They are known to eliminate free radicals such as Reactive Oxygen Species (ROS) in damaged tissues (Lacroix et al. 2004). They can scavenge radicals by electron transfer, hydrogen abstraction and addition. Conjugated double bonds qualify these compounds to accept electrons from reactive species, and then neutralize free radicals (Sznarkowska et al. 2016, Milani et al. 2016). It is worth reminding that PS cultivar presented the lowest content of $\beta$-carotene and the highest content of total phenolics and lycopene. Therefore, considering that ascorbic acid content was similar in all tested extracts, phenolic compounds and lycopene seemed to have contributed more importantly to the highest antioxidative activity found in PS cultivar. The correlation between AA and FRAP indicates that FRAP was the best used method to evaluate the AA of ascorbic acid.

As aforementioned, for the evaluation of the antitumorigenic effect of guava pulp extracts we used two cell lines derived from breast carcinoma because of their complementary characteristics. The star-shaped MDA-MB-435 epithelial cells do not express hormonal receptors and present high metastatic potential and high tumorigenicity (Netzel et al. 2007). The MCF-7 epithelial mesenchymal cell line, on the other hand, presents estrogen and progesterone receptors and low metastatic potential. These cells have a fusiform morphology and are luminal. However, they have low invasion potential in Matrigel, which is a meshwork of extracellular matrix proteins and growth factors that mimics the basement membrane underlying epithelial cells and have been broadly used for assessing cancer cell invasion, in vitro (Williams et al. 2000). In this study, the cell proliferation was evaluated by the MTT (3-(4,5-dimethylthiazol2-yl)-2,5-diphenyl tetrazolium bromide) assay, which is one of the most commonly used methods to access the action and interaction of natural products, like fruits and plants, on cell proliferation, viability and cytotoxicity. This assay is based on the reduction of a tetrazolium salt to a purple insoluble formazan by metabolically active cells. The absorbance of the solubilized formazan is taken as a measure of the number of living cells. In this essay, PS cultivar also presented the best results, with up to $70 \%$ reduction in MDA-MB-435 proliferation after 48 hours and $50 \%$ of MCF-7 cells in 24 hours. No 
further reduction in the proliferation of both cell lines was observed after these treatment times. Therefore, no evaluation was performed after these time points. It is noteworthy mentioning that we have evaluated the effect of P. guajava extract on normal breast cancer cell lines (MCF10A) and found no increase in cell death (data not shown).

Considering the major bioactive compounds found in PS pulp, the present study results suggest that polyphenols and/or lycopene were/was capable of inhibiting the growth of human breast adenocarcinoma cells. It is more probable that lycopene and anthocyanins acted together as antiproliferative agents, being supported by other bioactive compounds, including as $\beta$-carotene.

Previous studies have reported proliferation reduction (in one case by more than $60 \%$ at $200 \mu \mathrm{g} / \mathrm{mL}$ ) of different cancer cells caused by strawberry and grape anthocyanins (Palozza et al. 2002, Pandeyv et al. 2009). Other in vitro studies have also established the antitumorigenic effect of lycopene in several tumor types, including prostate colon, liver and lung cancer (Hwang and Bowen 2004). In addition to ROS scavenging, lycopene is known to act by modulating redox sensitive cell targets, including protein kinases, protein tyrosine phosphatases (PTP), Mitogen Activated Protein Kinase (MAPKs) and transcription factors (Palozza 2012). Lycopene has also exerted anti-proliferative effect on breast cancer cell model, reducing the expression of cell cycle regulatory proteins, such as cyclins (D1 and E) and cyclin-dependent kinases (-2 and -4), as well as suppressing insulin-like growth factor (IGF-I) action (Karas et al. 2000, Burgess et al. 2008, Teodoro et al. 2012). The complexes of cyclin and Cdk play key roles in the control of cell cycle progression. Cyclins contain a wellconserved amino acid sequence known as the cyclin box, which is required for the binding to and activation of specific target Cdks in each cell cycle phase (Malumbres 2014). These results have been supported by epidemiological studies in which the consumption of tomato (one of the main sources of lycopene) was associated with decreased risk of several types of cancer, including lung, prostate and colon cancer. Higher circulating levels of carotenoids in women have also been reported to reduce the risk of breast cancer (Eliassen et al. 2012). The consumption of $\beta$-carotene has also been inversely associated with the incidence of colon (Diehl 2002) and prostate (Bertoli et al. 2013) cancers.

Regarding the cell viability and cell cycle results, the lack of regulation of cell cycle is a fundamental aspect in cancer development. The normal cells only proliferate in response to the cell development or to signals that occur during mitosis. The cell cycle consists of distinct phases of events that occur in a cell in preparation for cell division: $G_{0}$ phase is viewed as an extended $\mathrm{G}_{1}$, (gap ${ }_{1}$, or $\mathrm{G} 1$, stage), copies its DNA (synthesis, or $\mathrm{S}$, stage), prepares to divide (gap 2, or $\mathrm{G}_{2}$, stage), and divides (mitosis, or $M$, stage). The stages $G_{1}, S$, and $G_{2}$ makeup and interphase, which accounts for the span between cell division (Prakash et al. 2001). Each phase of the cell cycle is tightly regulated, and checkpoints exist to detect potential DNA damage and allow it to be repaired before a cell divide. If damage cannot be repaired, a cell becomes targeted for apoptosis, which is a programmed cell death process that occurs in multicellular organisms, under different circumstances and involves different stages (Obermuller-Jevic et al. 2003).

The fact that in the cell cycle assay PS and $\mathrm{HI}$ pulp extracts increased the proportion of cells in the sub $G_{0}$ and reduced the total number of cells present in $G_{2} / M$, after 24 hours treatment, suggest a cell cycle interruption in $G_{0} / G_{1}$ phase, which makes impossible the progression to mitosis and multiplication. Therefore, considering the fact 
that guava extracts inhibited the proliferation and viability of adenocarcinoma breast cells, it is presumable that a smaller number of cells will be able to reach phases $S$ and $G_{2}$. In this study, especially PS and $\mathrm{HI}$ extracts increased the percentage of cells in the $G_{0} / G_{1}$ phase and decreased the percentage of cells in the $G_{2} / M$ phase in both MCF-7 and MDA-MB-435 lines. The cell cycle analysis revealed similarities with other studies that have reported the effect of lycopene on breast cancer to be associated with the inhibition of cell cycle progress through $\mathrm{G}_{0} / \mathrm{G}_{1}$ phases. It has been stated that this carotenoid is able to act as an antitumor agent by arresting cell proliferation and inducing apoptosis (Palozza et al. 2007) It has also been stated that lycopene treatment increased the percentage of cells in the $G_{0} / G_{1}$ phases in additional types of cancers such as colon and prostate cancer (Vuolo et al. 2019, Grivicich et al. 2007). Concerning anthocyanins, there are no reports on the anticarcinogenic effect of guava anthocyanins but in an ethanolic extract of red-jambo peel, anthocyanins content was strongly correlated with the antioxidant capacity evaluated by cellular antioxidant activity and oxygen radical absorbance capacity, and showed significant effect on reducing the tumoral cell growth and proliferation. Anthocyanins richblack chokeberry extracts were also able to inhibit cancer metastasis (Thi \& Hwang 2018). An anthocyanin rich-Java plum extract has suppressed proliferation of HCT-116 cells and elevated apoptosis in both HCT-116 cells and colon CSCs (Charepalli et al. 2016). Finally, an anthocyanins-rich extract markedly decreased caco-2 cell proliferation, induced apoptosis by activating caspase-3 cleavage, and upregulated cyclin-dependent kinase inhibitor 1 (p21Waf/ Cif1) expression in a dose dependent manner. Furthermore, this extract was able to produce a dose-dependent increase of intracellular ROS in
Caco-2 cells, together with an increase in the cell total antioxidant status (Prakashet et al. 2001).

In a normal situation, a programmed sequence of events leads to the elimination of cells without causing damage adjacent to tissues. The apoptosis process is responsible for keeping cells healthy, eliminating excess or abnormal cells. When abnormal cells fail to undergo apoptosis, the likelihood of mutations is increased, which can become carcinogenic cells. Apoptosis occurs by the action of a family of cysteine proteases, the caspases, which are activated in response to pro-apoptotic stimuli. Caspases promote apoptosis by: (a) inducing destructive enzymes such as DNases, (b) releasing cytochrome c via $\mathrm{Bcl}-2$ family proteins, and (c) destroying major structural and regulatory proteins (Anwar et al. 2016). Among the several types of cancer, evidences show that the resistance to apoptosis is one of the most characteristic traits of the majority of malign tumors (Willers et al. 2013). In the present study, guava extracts, especially PS and HI extracts, promoted increased apoptotic death, both in MCF-7 and in MDA-MB-435 cell lines. The inhibition of the growth of many human colon adenocarcinoma cell lines by carotenoids has been reported. They induce cell-cycle arrest and apoptosis and are responsible for reducing cyclin A, an important regulator of cell-cycle progression (Gloria et al. 2014).

\section{CONCLUSIONS}

The data presented in this study demonstrate that guava cultivars pulp extracts, especially Pedro Sato, can play an important role in the reduction of cancer cells viability, regulation of cell cycle, and in the control of tumor progression, via the induction of apoptosis. Additional studies need to be performed to 
confirm the higher anti-carcinogenic effect of Pedro Sato compared to other guava cultivars.

\section{Acknowledgments}

This study was funded by the Fundação de Amparo à Pesquisa do Estado do Rio de Janeiro (FAPERJ), grant numbers 246295, 246296 and 238719, and partly funded by the Coordenação de Aperfeiçoamento de Pessoal de Nivel Superior (CAPES) - Brazil, Finance Code 001.

\section{REFERENCES}

ADOLFO LUTZ INSTITUTE. 2005. Physicochemical methods for food analysis. $4^{\text {th }}$ ed., Brasilia: MS/ANVISA, $1018 \mathrm{p}$.

AL-MAHMOOD S, SAPIENZYNSKI J, GARBUZENKO OB \& MINKO T. 2018. Metastatic and triple-negative breast cancer: challenges and treatment options. Drug Deliv Transl Res 8: 1483-1507.

ALKHALAF M \& EL-MOWAFY AM. 2003. Overexpression of wildtype p53 gene renders MCF-7 breast cancer cells more sensitive to the antiproliferative effect of progesterone. J Endocrinol 179: 55-62.

ANWAR S, FRATANTONIO D, FERRARI D, SAIJA A, CIMINO F \& SPECIALE A. 2016. Berry anthocyanins reduce proliferation of human colorectal carcinoma cells by inducing caspase-3 activation and p21 upregulation. Mol Med Rep 14: $1397-1403$.

ASSAR EA, VIDALLE MC, CHOPRA M \& HAFIZI S. 2016. Lycopene acts through inhibition of ikappaB kinase to suppress NFkb1 signaling in human prostate and breast cancer cells. Tumour Biol 37: 9375-9385.

BARREIROS ALBS, DAVID JM \& DAVID JP. 2006. Oxidative stress: relationship between generation and reactive species and body's defenses. Quím Nova 29: 113-123.

BENZIE IF \& STRAIN JJ. 1996. The ferric reducing ability of plasma (FRAP) as a measure of "antioxidant power": the FRAP assay. Anal Biochem 239: 70-76.

BERTOLI C, SKOTHEIM JM \& BRUIN RAM. 2013. Control of cell cycle transcription during G1 and S phases. Nat Rev Mol Cell Bio 14: 518-528.

BRAND-WILLIAM W, CUVELIER ME \& BERSET C. 1995. Use of a free radical method to evaluate antioxidant activity. LWTFood Sci Tech 28: 25-30.

BRAY F, FERLAY J, SOERJOMATARAM I, SIEGEL RL, TORRE LA \& JEMAL A. 2018. Global cancer statistics 2018: GLOBOCAN estimates of incidence and mortality worldwide for 36 cancers in 185 countries. CA Cancer J Clin 68: 394-424.

BRISKEN C \& O'MALLEY B. 2010. Hormone action in the mammary gland. Cold Spring Harb Perspect Biol 2: 31-78.

BURGESS LC, RICE E, FISCHER T, SEEKINS JR, BURGESS TP, STICKA S) \& KLATT K. 2008. Lycopene has limited effect on cell proliferation in only two of seven human cell lines (both cancerous and noncancerous) in an in vitro system with doses across the physiological range. Toxicol In Vitro 22: $1297-1300$

CAETANO ACS, ARAÚJO CR, LIMA VLAG, MACIEL MIS \& MELO EA. 2011. Evaluation of antioxidant activity of agro-industrial waste of acerola (Malpighia emarginata D.C.) fruit extracts. Food Sci Tech 31: 769-775.

CHAHAL A, SAINI A, CHHILLAR AK \& SAINI R. 2018. Natural antioxidants as defense system against cancer. Asian J Pharm Clin Res 11: 38-44.

CHALABI N, DELORT L, LE CORRE L, SATIH S, BIGNON, YJ, BERNARDGALLON D. 2006. Gene signature of breast cancer cell lines treated with lycopene. Pharmacogenomics 7(5): 663-672.

CHALABI N, SATIH S, DELORT L, BIGNON YJ, BERNARD-GALLON DJ. 2007. Expression profiling by whole-genome microarray hybridization reveals differential gene expression in breast cancer cell lines after lycopene exposure. Biochim Biophys Acta Gene Struct Expr 1769(2): 124-130.

CHAREPALLI V, REDDIVARI L, VADDE R, WALIA S, RADHAKRISHNAN \& VANAMALA JKP. 2016. Eugenia jambolana (java plum) fruit extract exhibits anti-cancer activity against early stage human HTC-116 colon cancer cells and colon cancer stem cells. Cancers 8: 29.

CHIARI-ANDRÉO BG, TROVATTI E, MARTO J, ALMEIDA-CINCOTTO MGJ, MELERO A, CORREA MA, CHIAVACCI LA, RIBEIRO H, GARRIGUES T \& ISAAC VLB. 2017. Guava: phytochemical composition of a potential source of antioxidants for cosmetic and/or dermatological applications. Braz J Pharm Sci 53: 1-10.

CHIARI BG, SEVERI JA, DE PAULI-CREDENDIO PA, SYLOS CM, VILEGAS W, CORREA MA \& ISAAC VLB. 2012. Assessment of the chemical profile, polyphenol content and antioxidant activity in extracts of Psidium Guajava L. fruits. Int J Pharm Pharm Sci 4: 331-336.

CHITARRA MIF \& CHITARRA AB. 2005. Fruit and vegetable postharvest: Physiology and handling, $2^{\text {nd }}$ ed., Lavras: Federal University of Lavras, 783 p.

CORREA MG, COUTO JS \& TEODORO AJ. 2016. Anticancer properties of Psidium guajava - a mini-review. Asian Pac J Cancer Prev 17: 4199-4204. 
DÁVALOS A, BARTOLOMÉ B \& GÓMEZ-CORDOVÉS C. 2005. Antioxidant properties of commercial grape juices ant vinegars. Food Chem 93: 325-330.

DIEHL JA. 2002. Cycling to cancer with cyclin D1. Cancer Biol Ther 1: 226-231.

DOS SANTOS RC et al. 2017. Lycopene-rich extract from red guava (Psidium guajava L.) displays cytotoxic effect against human breast adenocarcinoma cell line MCF-7 via an apoptotic-like pathway. Food Res Int 105:184-196.

FIEDOR J \& BURDA K. 2014. Potential role of carotenoids as antioxidants in human health and disease. Nutrients 6 : 466-488.

FU L, XU BT, XU XR, GAN RY, ZHANG Y, XIA EQ \& LI HB.2011. Antioxidant capacities and total phenolic contents of 62 fruits. Food Chem 129: 345-350.

GLORIA NF, SOARES N, BRAND C, OLIVEIRA FL, BOROJEVIC R \& TEODORO AJ. 2014. Lycopene and beta-carotene induce cell-cycle arrest and apoptosis in human breast cancer cell lines. Anticancer Res 34: 1377-1386.

GONZALEZ H, HAGERLING C \& WERB Z. 2018. Roles of the immune system in cancer: from tumor initiation to metastatic progression. Genes Dev 32: 1267-1284.

GOULD WP \& RAGA A. 2002. Pests of guava, p. 295-313. In: Peña JE, Sharp JL \& Wysoki M (Eds), Tropical fruit pests and pollinators: Biology, economic importance, natural enemies and control. Wallingford, CAB, 430 p.

HOU DX, FUJII M, TERAHARA N \& YOSHIMOTO M. 2004. Molecular mechanisms behind the chemopreventive effects of anthocyanidins. J Biomed Biotechnol 5: 321-325.

HUANG D, OU B \& PRIOR RL. 2005. The chemistry behind antioxidant capacity assays. J Agric Food Chem 53: 1841-1856.

HWANG ES \& BOWEN PE. 2004. Cell cycle arrest and induction of apoptosis by lycopene in LNCaP human prostate cancer cells. J Med Food 7: 284-289.

IARC/WHO. 2018. Available at: <https://www.who.int/ cancer/PRGlobocanFinal.pdf> Access on: December 2018.

IBGE - INSTITUTO BRASILEIRO DE GEOGRAFIA E ESTATÍSTICA. 2019. Agricultural municipal production/PAM.

INCA. 2019. Disponivel em: <https://www.inca.gov.br/ tipos-de-cancer/cancer-de-mama> Acessado em: Janeiro de 2019.

JANG SH, LIM JW, MORIO T \& KIM H. 2012. Lycopene inhibits helicobacter pylori-induced ATM/ATR-dependent DNA damage response in gastric epithelial AGS cells. Free Radic Biol Med 52: 607-615.
JOSEPH B \& PRIYA M. 2011. Review on nutritional, medicinal and pharmacological properties of guava (Psidium guajava Linn.). Int J Pharma Bio Sci 2: 53-69.

KARAS M, AMIR H, FISHMAN D, DANILENKO M, SEGAL S, NAHUM A, KOIFMANN A, GIAT Y LEVY J \& SHARONI Y. 2000. Lycopene interferes with cell cycle progression and insulin-like growth factor I signaling in mammary cancer cells. Nutr Cancer 36: 101-111.

KHOO HE, AZLAN A, TANG ST \& LIM SM. 2017. Anthocyanidins and anthocyanins: colored pigments as food, pharmaceutical ingredients, and the potential health benefits. Food Nutr Res 61: 779.

KING-BATOON A, LESZCZYNSKA JM \& KLEIN CB. 2008. Modulation of gene methylation by genistein or lycopene in breast cancer cells. Environ Mol Mutagen 49(1): 36-45.

KUSKOSKI EM, ASUERO AG, MORALES MT \& FETT R. 2006. Wild fruits and pulps of frozen fruits: antioxidant activity, polyphenols and anthocyanins. Scien Rural 36: 1283-1287.

KUSKOSKI EM, ASUERO EG, TRONCOSO AM, MANCINI-FILHO J \& FETT R. 2005. Application of various chemical methods to determine antioxidant activity in fruit pulp. Ciênc Tec Alim 25: 726-732.

LACROIX M, TOILLON RA \& LECLERCQ G. 2004. Stable 'portrait'of breast tumors during progression: data from biology, pathology and genetics. Endocr-Relat Cancer 11: 497-522.

LEE SB \& PARK HR. 2010. Anticancer activity of guava (Psidium guajava L.) branch extracts against HT-29 human colon cancer cells. J Med Plants Res 4: 891-896.

LEVY AS \& CARLEY SK. 2012. Cytotoxic activity of hexane extracts of Psidium guajava L. (Myrtaceae) and Cassia alata L. (Caesalpineaceae) in Kasumi-1 and OV2008 cancer cell lines. Trop J Pharm Res 11: 201-207.

LIU RH. 2004. Potential synergy of phytochemicals in cancer prevention: mechanism of action. J Nutr 134: 3479S-3485S.

MALUMBRES M. 2014. Cyclin-dependent kinases. Genome Biol 15: 122.

MANICA I, JUNQUEIRA NTV, SALVADOR JO, MOREIRA A, MALAVOLTA E. 2000. Eds. tropical fruit-6: guava. O porto alegre: five continents. cap. 5: 85-111.

MARTÍNEZ R, TORRES P, MENESES MA, FIGUEROA JG, PÉREZÁLVEREZ JA \& VIUDA-MARTOS M. 2012. Chemical, technological and in vitro antioxidant properties of mango, guava, pineapple and passion fruit dietary fibre concentrate. Food Chem 135: 1520-1526. 
MILANI A, BASIRNEJAD M, SHAHBAZI S \& BOLHASSANI A. 2016. Carotenoids: biochemistry, pharmacology and treatment. Br J Pharmacol 174: 1290-1324.

NASCIMENTO P. 2006. Retention rating of pumpkin, cassava and sweet potatoe's carotenoids. Dissertation (Master degree on food science engineering) Paulista State University. (Unpublished).

NETZEL M, NETZEL G, KAMMERER DR, SHIEBER A, CARLE R, SIMONS L, BITSCH I, BITSCH R \& KONKCZAK I. 2007. Cancer cell antiproliferation activity and metabolism of black carrot anthocyanins. Innovative Food Sci Emerging Tech 8: 365-372.

NIEDZWIECKI A, ROOMI M, KALINOVSKY T \& RATH $M$. 2016. Anticancer efficacy of polyphenols and their combinations. Nutrients 8: 552.

NORA CD, JABLONSKI A, RIOS AO, HERTZ PF, JONG EV \& FLÔRES $\mathrm{SH}$. 2014. The characterization and profile of bioactive compounds in red guava (Psidium cattleyanum Sabine) and guabiju (Myrcianthes pungens (O. Berg) D. Legrand). Int J Food Sci Tech 49: 1842-1849.

OBERMULLER-JEVIC UC, OLANO-MARTIN E, CORBACHO AM, EISERICH JP, VAN DER VLIET A, VALACCHI G, CROSS CE \& PACKER L. 2003. Lycopene inhibits the growth of normal human prostate epithelial cells in vitro. J Nutr 133: 3356-3360.

PACHECO S, PEIXOTO FM, BORGUINI RG, NASCIMENTO LSM, BOBEDA CRR, SANTIAGO MCPA \& GODOY RLO. 2014. Microscale extraction method for HPLC carotenoid analysis in vegetable matrices. Sci Agric 71: 416-419.

PALOZZA P, CATALANO A, SIMONE R \& CITTADINI A. 2012. Lycopene as a guardian of redox signalling. Acta Biochim Pol 59(1): 21-25.

PALOZZA P, COLANGELO M, SIMONE R, CATALANO A, BONINSEGNA A, LANZA P, MONEGO G \& RANELLETTI FO. 2010. Lycopene induces cell growth inhibition by altering mevalonate pathway and ras signaling in cancer cell lines. Carcinogenesis 31: 1813-1821.

PALOZZA P, SERINI S, BONINSEGNA A, BELLOVINO D, LUCARINI M, MONASTRA G \& GAETANI S. 2007. The growth-inhibitory effects of tomatoes digested in vitro in colon adenocarcinoma cells occur through down regulation of cyclin D1, Bcl-2 and Bcl-xL. Br JNutr 98: 789-795.

PALOZZA P, SERINI S, MAGGIANO N, ANGELINI M, BONINSEGNA A, DI NICUOLO F, RANELLETTI FO \& CALVIELLO G. 2002. Induction of cell cycle arrest and apoptosis in human colon adenocarcinoma cell lines by $\beta$-carotene through down-regulation of cyclin $\mathrm{A}$ and $\mathrm{Bcl}-2$ family proteins. Carcinogenesis 23: 11-18.
PANDEYV, DIXIT V \& SHYAM R. 2009. Chromium effect on ROS generation and detoxification in pea (Pisun sativum) leaf chloroplasts. Protoplasma 236: 85-95.

PARK B, LIM JW \& KIM H. 2019. Lycopene treatment inhibits activation of Jak1/Stat3 and Wnt/ $\beta$-catenin signaling and attenuates hyperproliferation in gastric epithelial cells. Nutr Res 70: 70-81.

PARK YO, HWANG ES \& MOON TW. 2005. The effect of lycopene on cell growth and oxidative DNA damage of Hep3B human hepatoma cells. Biofactors 23: 129-139.

PENG S, LI J, ZHOU Y, TUO M, QIN X, YU Q \& LI Y. 2017. In vitro effects and mechanisms of lycopene in MCF-7 human breast cancer cells. Genet Mol Res 16(2): 1-8.

PRAKASH P, RUSSEL RM \& KRINSKY NI. 2001. In vitro inhibition of proliferation of estrogen-dependent and estrogenindependent human breast cancer cells treated with carotenoids or retinoids. J Nutr 131: 1574-1580.

RAMOS S. 2008. Cancer chemoprevention and chemotherapy: dietary polyphenols and signalling pathways. Mol Nutr Food Res 52: 507-526.

RE R, PELLEGRINI N, PROTEGGENTE A, PANNALA A, YANG M \& RICEEVANS C. 1999. Antioxidant activity applying an improved ABTS radical cation decolorization assay. Free Radic Biol Med 26: 1231-1237.

REISCHE DW, LILLARD DA \& EITENMILLER RR. 2002. Antioxidants. In: Akoh CC and Min DB. Food lipids: chemistry, nutrition and biotechnology. $2^{\text {nd }}$ ed., New York: Marcel Dekker, 489-516.

RIBEIRO DM, FERNANDES DC, ALVES AM \& NAVES MMV. 2014. Carotenoids are related to the colour and lipid content of the pequi (Caryocar brasiliense Camb.) pulp from Brasilian Savanna. Food Sci Technol 34: 507-512.

ROCHA RIBEIRO SM, QUEIROZ JH, LOPES RIBEIRO DE QUEIROZ ME, CAMPOS FM \& PINHEIRO SANT'ANA HM. 2007. Antioxidant in mango (Mangifera indica L.) pulp. Plant Food Hum Nutr 62: 13-17.

RODRIGUEZ-AMAYA DB. 2001. A guide to carotenoid analysis in food. Washington D.C. ILSI Human Nutrition Institute, $64 \mathrm{p}$.

SINGLETON VL \& ROSSI JA. 1965. Colorimetry of total phenolics with phosphomolybdic-phosphotungstic acid reagents. Am J Enol Vitic 16: 144-158.

STAHL W \& SIES H. 1996. Lycopene: a biologically important carotenoid for humans? Arch Biochem Biophys 336: 1-9.

SZNARKOWSKA A, KOSTECKA A, MELLER K \& BIELAWSKI KP. 2017. Inhibition of cancer antioxidant defense by natural compounds. Oncotarget 8: 15996-16016. 
TAKESHIMA M, ONO M, HIGUCHI T, CHEN C, HARA T \& NAKANO S. 2014. Antiproliferative and apoptosis-inducing activity of lycopene against three subtypes of human breast cancer cell lines. Cancer Sci 105(3): 252-257.

TEODORO AJ, OLIVEIRA FL, MARTINS NB, MAIA GA, MARTUCCI RB \& BOROJEVIC R. 2012. Effect of lycopene on cell viability and cell cycle progression in human cancer cell lines. Cancer cell Int 12: 36.

TOYOKUNI S. 2016. Oxidative stress as an iceberg in carcinogenesis and cancer biology. Arch Biochem Biophys 595: 46-49.

THI ND \& HWANG ES. 2018. Effects of black chokeberry extracts on metastasis and cell-cycle arrest in SK-Hep1 human liver cancer cell line. Asian Pac J Trop Biomed 8: 285-291.

USDA. 2006. Agricultural Research Service: Nutrient Data Laboratory. Washington. Available at: <www.nal.usda. gov/fnic/foodcomp> Access on: September 2019.

VINDELOV LL. 1977. Flow microfluorometric analysis of nuclear DNA in cells from solid tumors and cell suspensions. A new method for rapid isolation and staining of nuclei. Virchows Arch B 24: 227-242.

VUOLO MM, BATISTA AG, BIASOTO ACT, CORREA LC, MARÓSTICA JUNIOR MR \& LIU RH. 2019. Red-jambo peel extract shows antiproliferative activity against HepG2 human hepatoma cells. Food Res Int 124: 93-100.

WEIGEL MT \& DOWSETT M. 2010. Current and emerging biomarkers in breast cancer: prognosis and prediction. Endocr Relat Cancer 17: 245-262.

WILLERS H, AZZOLI CG, SANTIVASI WL \& XIA F. 2013. Basic mechanisms of therapeutic resistance to radiation and chemotherapy in lung cancer. Cancer J 19: 200-207.

WILLIAMS AW, BOILEAU TW, ZHOU JR, CLINTON SK \& ERDMAN JR JW. 2000. Beta-carotene modulates human prostate cancer cell growth and may undergo intracellular metabolism to retinol. J Nutr 130: 728-732.

WHO - WORLD HEALTH ORGANIZATION. 2013. Available at: <http: //www.who.int/en/> Access on: February 2013.

\section{How to cite}

CORREA MG, COUTO JS, TRINDADE BB, ABREU JP, NAKAJIMA VM, OLIVEIRA FL, FARAH A \& TEODORO AJ. 2020. Antiproliferative effect of guava fruit extracts in MDA-MB-435 and MCF-7 human breast cancer cell lines. An Acad Bras Cienc 92: e20191500. DOI 10.1590/0001-3765202020191500.

Manuscript received on December 3, 2019; accepted for publication on February 11, 2020

\section{MARIANA G. CORREA}

https://orcid.org/0000-0003-4778-858X

\section{JESSICA S. COUTO}

https://orcid.org/0000-0001-9484-2388

\section{BRUNO B. TRINDADE}

https://orcid.org/0000-0003-4871-5817

JOEL P. ABREU ${ }^{1}$

https://orcid.org/0000-0003-2994-7823

VANIA M. NAKAJIMA ${ }^{2}$

https://orcid.org/0000-0003-0705-0708

FELIPE L. OLIVEIRA ${ }^{3}$

https://orcid.org/0000-0001-6193-1616

\section{ADRIANA FARAH ${ }^{4}$}

https://orcid.org/0000-0002-7584-5564

\section{ANDERSON J. TEODORO}

https://orcid.org/0000-0002-0949-9528

'Universidade Federal do Estado do Rio de Janeiro, Departamento de Ciência dos Alimentos, Laboratório de Alimentos Funcionais (LAAF), Av. Pasteur, 296, 22290-240 Rio de Janeiro, RJ, Brazil

${ }^{2}$ Universidade Federal Fluminense, Departamento de Nutrição e Dietética, Rua Mário Santos Braga, 28, 24110-010 Niterói, RJ, Brazil

${ }^{3}$ Universidade Federal do Rio de Janeiro, Instituto de Ciências Biomédicas, Av Carlos Chagas Filho, 393, 21941-902 Rio de Janeiro, RJ, Brazil

${ }^{4}$ Universidade Federal do Rio de Janeiro, Instituto de Nutrição, Av. Carlos Chagas Filho, 373, 21941-902

Cidade Universitária, Rio de Janeiro, RJ, Brazil

Correspondence to: Anderson Junger Teodoro

E-mail:atteodoro@gmail.com

\section{Author contributions}

Conceptualization, M.G.C. and A.J.T.; methodology, M.G.C., J.S.C., B.B.T., J.P.A., F.L.O. and A.J.T.; data curation, M.G.C., J.S.C., B.B.T., J.P.A., F.L.O., V.M.N., A.F. and A.J.T.; writing-original draft preparation, M.G.C., J.S.C., B.B.T., J.P.A., F.L.O., V.M.N., A.F. and A.J.T.; writingreview and editing, M.G.C., J.S.C., B.B.T., J.P.A., F.L.O., V.M.N., A.F. and A.J.T.

(c) $B Y$ 